\title{
NEONATAL HYPOGLYCEMIA: RISK FACTORS AND OUTCOMES
}

\author{
Orhideja Stomnaroska ${ }^{1}$, Elizabeta Petkovska ${ }^{1}$, Snezana Jancevska $^{1}$, Dragan Danilovski ${ }^{2}$ \\ ${ }^{1}$ University Clinic for Gynecology and Obstetrics, Medical Faculty Skopje, Macedonia \\ ${ }^{2}$ Institute for Epidemiology and Statistics, Medical Faculty Skopje, Macedonia
}

Corresponding author: Orhideja Stomnaroska, University Clinic for Gynecology and Obstetrics, Medical Faculty Skopje, Vodnjanska BB, 1000 Skopje, Macedonia; e-mail: stomnaroskao@yahoo.com

\begin{abstract}
Background and aims: Severe neonatal hypoglycemia (HG) leads to neurologic damage, mental retardation, epilepsy, personality disorders, impaired cardiac performance and muscle weakness. We aimed to assess the clinical characteristics of children with hypoglycemia in a random population of newborns.

Patients, methods and results: We investigated 84 patients $(\mathrm{M}: \mathrm{F}=35: 48)$ born at the University Clinic for Gynecology and Obstetrics in Skopje (hospitalized in the NICU) who were found to have hypoglycemia. In total $89.25 \%$ of the babies were premature. The mean birth weight was $1795.95+/ 596.08$ grams, the mean birth length was $41.92+/-4.62 \mathrm{~cm}$, while the mean gestational age was $33.05 \pm 3.19$ weeks. 32 children $(38.08 \%)$ were very low birth weight $(<1500 \mathrm{~g}), 38(45.22 \%)$ were low birth weight $(1500-2500 \mathrm{~g})$, while there were 8 children $(9.52 \%)$ appropriate for age BW and no high BW for age patients $(>4000 \mathrm{~g})$.

HG duration was $2.42+/-2.41$ hours. In the group as a whole, hypoxic-ischemic encephalopathy (HIE) was found in 3 children (3.57\%), infections in $22(26.18 \%)$, respiratory distress syndrome (RDS) in 9 patients $(10.62 \%)$, intracranial haemorrhage in 2 patients $(2.38 \%)$. There were no inborn errors of metabolism. There were two deaths $(2.38 \%)$.

Conclusion: Neonatal HG is a significant factor in the overall neonatal mortality. HG can also cause severe invalidity. We found that infections, LBW and low gestational age were most commonly associated with neonatal HG. However the Spearman test showed weak direct correlation, without statistical significance. Neonatal HG requires complex and team interaction of prenatal and postnatal approaches to reduce the incidence of seizures, their consequences and the overall mortality. Special consideration is to be taken in measures that avoid neonatal infections, HIE, LBW and low gestational age. Further studies on a larger population are needed to fully understand and prevent the phenomenon of HG in newborns.
\end{abstract}

Keywords: neonatal hypoglycemia, co-morbidities, low birth weight, HIE, mortality.

\section{INTRODUCTION}

The neonatal period is marked by increased risk of HG and seizures (1-3). Neonatal HG is the most common form of a metabolic disturbance in newborns, while seizures are the most common symptom of neurological dysfunction $(2,3)$. The incidence of neonatal seizure is high: $10-25 \%$ in neonatal intensive care units (NICU). Strikingly in NICU $15 \%$ of newborns with seizures will die and $35-40 \%$ will have significant neurological defects (2).
Hypoxic-ischemic encephalopathy (HIE) is found in $\sim 50 \%$ of the patients with neonatal $\mathrm{HG}$ (1). HIE may potentiate the permanent brain damage caused by HG (3). In neonates there are multiple other causative factors for HG: intracranial hemorrhage, infections, metabolic disorders, CNS malformations, birth trauma, and metabolic disorders $(2,3)$.

Delay in therapy often results in poor neurological outcome $(4,5)$. It is of note that the worst neurological outcome in large number of children is 
observed in neonates and infants with persistent and recurrent severe hypoglycemia $(3,6)$.

We aimed to assess the incidence, etiology, and outcome of HG in newborns hospitalized at the neonatal ward and NICU of the University Clinic for Gynecology and Obstetrics.

\section{PATIENTS AND METHODS}

This study was carried out in the neonatal intensive care unit of University Clinic for Gynecology and Obstetrics in Skopje, Macedonia.

The following classification of neonatal $\mathrm{HG}$ was applied: capillary blood glucose $(\mathrm{CBG})$ values were considered normal when $\geq 2.5 \mathrm{mmol} / \mathrm{l}$, or $\mathrm{HG}$ was mild (2.2-2.4 mmol/1), moderate $(1.6-2.1 \mathrm{mmol} / \mathrm{l})$ or severe $\mathrm{HG}(<1.6 \mathrm{mmol} / \mathrm{l})(7)$.

The diagnosis of neonatal seizures was based on clinical observation, multiple measurements of CBG (from the first hour after birth, than consecutively the $3^{\text {rd }}, 6^{\text {th }}$ hour of life, and/or until the resolution of the HG episode. The etiology of the seizures was assessed using clinical examination, laboratory results, and/or imaging (ultrasound).

The Diagnosis of HIE was determined by analyzing data from the medical history and physical examination, taking into regard the Apgar score, arterial blood gas results, and neuroimaging. The American Academy of Pediatrics and the American College of Obstetricians and Gynecologists defined those features for the diagnosis of birth asphyxia: 1) Profound metabolic or mixed acidemia $(\mathrm{pH}<7.00)$ in umbilical arterial blood. 2) Apgar score of 0-3>5 minute after birth. 3) Signs of neonatal encephalopathy (seizures, coma, or hypotonia), 4) Multiple organ involvement (kidney, lungs, liver, heart, intestines). Children were breastfed, rarely formulas were used..

Clinical examination, blood cell count, $\mathrm{C}$ reactive protein, and positive blood culture lead to the diagnosis of sepsis. Pulmonary infections were diagnosed clinically and confirmed by microbiological analysis of the deep tracheal aspiration. The existence of intracranial hemorrhage was demonstrated with US or CT scan.

The biochemical analysis was performed using the ARCHITECT plus c4000, Integra 400.

The statistical analysis included parametric and non-parametric statistics using SPSS software.

\section{RESULTS}

We investigated 84 patients $(\mathrm{M}: \mathrm{F}=35: 48)$ as a random group born at the University Clinic for Gynecology and Obstetrics and admitted to the NICU in
Skopje. The delivery in 33 (39.27\%) cases was vaginal, and in $51(60.69 \%)$ caesarean section. Among all the patients $89.25 \%$ were preterm.

The mean birth weight was $1795.95+/ 596.08$ grams, the mean birth length was $41.92+/-4.62 \mathrm{~cm}$. 32 children $(38.08 \%)$ were very low birth weight $(<1500 \mathrm{~g}), 38(45.22 \%)$ were low birth weight $(1500$ $2500 \mathrm{~g})$, while there were 8 children $(9.52 \%)$ appropriate for age BW and no high BW for age patients (>4000 g) (Fig 1).

The Apgar score was $6.65+/-1.11$ at 0 minutes and $7.17+/-1.19$ at 5 minutes.

The blood glucose level at 0 hours was $2.17+/-$ 0.17 , at one hour $4.08+/-1.9$. at 2 hours $4.37+/-1.74$, at 3 hours $4.17+/-2.002$, at 4 hours $4.39+/-1.89$ and at 5 hours the glycaemia was $4.28+/-1.86 \mathrm{mmol} / 1$. HG duration was $2.42+/-2.41$ hours. In the group as a whole, hypoxic-ischemic encephalopathy (HIE) was found in 3 children (3.57\%), infections in 22 $(26.18 \%)$, respiratory distress syndrome (RDS) in 9 patients $(10.62 \%)$, intracranial hemorrhage in 2 patients (2.38\%) (Fig.2).

There were no inborn errors of metabolism. There were two deaths $(2.38 \%)$ in children with infections, low birth weight and hypoglycemia.

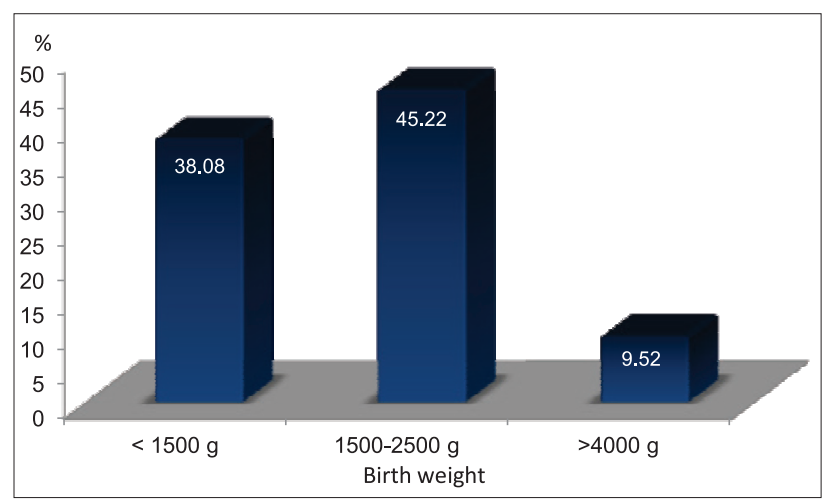

Figure 1: Birth weight distribution

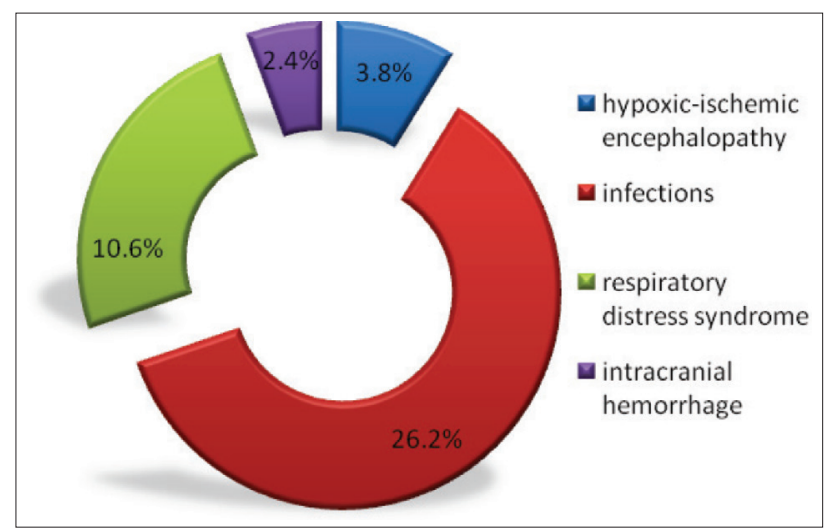

Figure 2: Co-morbidities in children with neonatal hypoglycaemia 
Although the Spearman test showed weak direct correlation, there was not statistical significance for the association among $\mathrm{HG}$ and infections (multiple $\mathrm{R}=0,752101 ; \mathrm{p}=0,526683$ ), gender (multiple $\mathrm{R}=0,782301 ; \mathrm{p}=0,577641)$, LBW $(0,114932$ weak direct correlation, but no statistical significance $\mathrm{p}=0,347025)$ (Fig. 1 ) and low gestational age $(-0,112608$ weak direct correlation, but no statistical significance $\mathrm{p}=0,307799$ ) (Fig. 3). HIE and HG were not correlated, probably due to the low number of patients with HIE (3 patients).

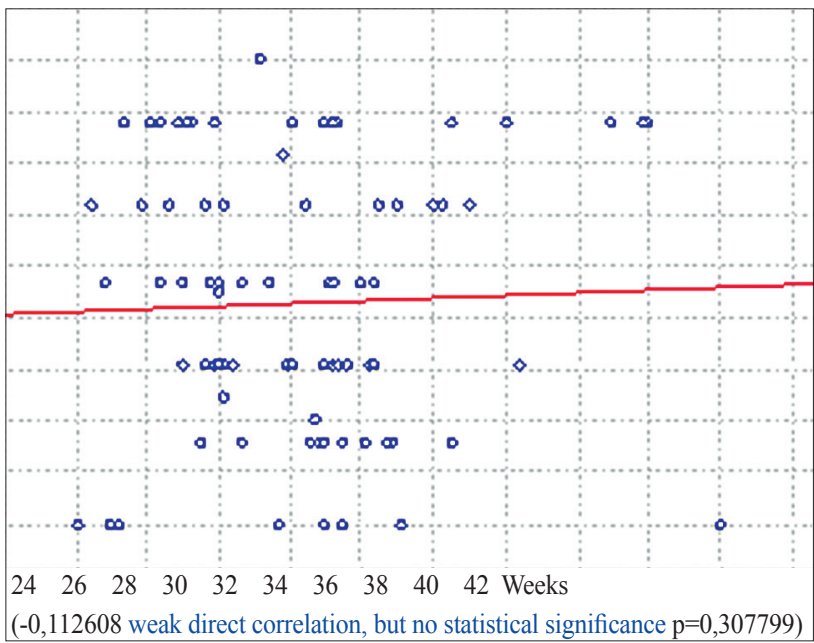

Figure 3: Birth age and hypoglycaemia

\section{DISCUSSION}

In neonates long term sequelae can occur within a wide range of low serum glucose values. Even transient moderate HG can result in neurological damage (8). The duration and severity of $\mathrm{NH}$ greatly influences the creation of permanent neurological damage, although the nadir glucose concentrations and the duration of $\mathrm{HG}$ that can damage newborn brain are not precisely determined $(2,3)$.

Serum glucose levels in neonates normally decline until age 1-3 hours and spontaneously increase afterwards. In fact, there is no rigorously determined specific blood glucose concentration for a definition of $\mathrm{NH}$ for infants (9-15).

The definition of neonatal HG that we used for the study was that of the clinical settings. HG in newborns was defined by a plasma glucose level of less than $30 \mathrm{mg} / \mathrm{dL}(1.65 \mathrm{mmol} / \mathrm{L})$ in the first 24 hours of life and less than $45 \mathrm{mg} / \mathrm{dL}(2.5 \mathrm{mmol} / \mathrm{L})$ thereafter. Many experts recommend that values of blood glucose $<50 \mathrm{mg} / \mathrm{dL}$ in neonates should be vigorously treated (3).

As previous studies have already reported estimating the frequency of neonatal HG many factors can be influenced by many factors: the definition used, the type of glucose assay, the compartment measured (serum, whole blood), the population investigated, the method and timing of feeding.

In the USA NHG is estimated to 1.3-3 per 1000 live births (2), while in Japan, among neonates born at 35-36 weeks' gestation $>80 \%$ of admissions to the NICU after birth were due to apnea or HG (16). Other authors (17-22) report an incidence between 7-11\%. Population-based studies (Harris County, USA) reported an incidence of 1-3.5/1000 live birth (I 3). There is an expected high incidence in NICU: $10-25 \%$ (23).

We also observed that all the neonates had HG of early onset (before 72 hours). Mostly neonatal HG was early: $59.6 \%$ and $81 \%$ of neonates had early onset seizure in reports by different authors $(23,26)$.

In addition we also found that HIE was not the most frequent factor in NHG seizures (3.57\%). HIE was the most frequent factor described by other authors $(17,24,25)$. HIE may potentiate the role of HG in causing brain damage. Contrary to our results many authors reported that the HIE is the leading cause of neonatal HG and seizures (27-29).

Infections were the most common finding in children our study: $26.18 \%$. Reported prevalence of seizures among children with infections is between 24.5 and $28.7 \%(17,23)$. This difference might be due to the high number of risk deliveries in our hospital. Exact causes remain to be determined.

Intracranial bleeding in this series of patients was found in $2.38 \%$ of newborns. Others have found a higher percentage of intracranial bleeding: $6.9 \%$ $-9.0 \%(1,17,23)$. Differences in the observed frequency stem from the different populations of patients: full-term versus pre-term, LBW versus $\mathrm{ABW}$, patients from neonatal wards versus NICU.

The overall mortality remains high, especially in children with co-morbidities. HIE and infections are the most common leading causes of death. The mortality rates ranged between 9 and $14.7 \%(2,17)$. We had a mortality of $2.38 \%$.

The most common risk factors for neonatal HG were asphyxia, birth weight less than $1500 \mathrm{~g}$, sepsis, convulsion, and meningitis $(2,3,31)$. EEG is a gold standard for neonatal epilepsy (32). Among many other measures in lowering the neonatal HG, there is no evidence that the universal screening of glucose levels in the first hours should be applied to all newborn infants (33).

In conclusion, neonatal $\mathrm{HG}$ is a major factor in neonatal mortality (34). Neonatal HG is also a major factor in permanent neurological consequences. It is of note that major contributing factors for neonatal 
HG should be actively searched and preventive measures must be taken in a timely manner. In this study LBW, low gestational age, HIE and high percentage of neonatal infections were the most frequent conditions associated with neonatal HG. It is of note that a larger group of patients is needed for more reliable data. Nevertheless it is obvious that preventive measures should address the LBW, HIE, infections and the low gestational age.

\section{REFERENCES}

1. Loman AM, ter Horst HJ, Lambrechtsen FA, Lunsing RJ. Neonatal seizures: aetiology by means of a standardized work-up. Eur J Paediatr Neurol. 2014;18(3):360-7.

2. WHO ref. number $\mathrm{WHO} / \mathrm{CHD} / 97.1 / \mathrm{WHO} /$ MSM/97.1 Hypoglycaemia in the newborn. Geneva: World Health Organization. 1997, 4, 19.

3. Sperling M. Hypoglycaemia. In: Nelson Textbook of Pediatrics, Saunders, Philadelphia, 2007; 655-669.

4. Hawdon JM, Ward Platt MP, Aynsley-Green A. Prevention and management of neonatal hypoglycemia. Arch Dis Child Fetal Neonatal Ed. 1994;70(1):F60-F64.

5. Mehta A. Prevention and management of neonatal hypoglcaemia. Arch Dis Child. 1994;70(1):F54-F65.

6. Menni F, de Lonlay P, Sevin C, et al. Neurologic outcomes of 90 neonates and infants with persistent hyperinsulinemic hypoglycemia. Pediatrics. 2001;107:476-479.

7. Flores-le Roux JA, Sagarra E, Benaiges D, Hernandez-Rivas E, Chillaron JJ, Puig de Dou J, Mur A, Lopez-Vilchez MA, Pedro-Botet J. A prospective evaluation of neonatal hypoglycaemia in infants of women with gestational diabetes mellitus. Diabetes Res Clin Pract. 2012;97(2):217-22.

8. Lucas A, Morley R, Cole TJ. Adverse neurodevelopmental outcome of moderate neonatal hypoglycaemia. Br Med J. 1988;297(6659):1304-1308.

9. Bonacruz GL, Arnold JD, Leslie GI, Wyndham L, Koumantakis G. Survey of the definition and screening of neonatal hypoglycaemia in Australia. J Paediatr Child Health. 1996;32(4):299301.

10. Laptook A, Jackson GL. Cold stress and hypoglycemia in the late preterm ("near-term") infant: impact on nursery of admission. Semin Perinatol. 2006;30(1):24-27.
11. Canadian Pediatric Society. Screening guidelines for newborns at risk for low blood glucose. Paediatr Child Health. 2004;9(10).

12. Rozance PJ, Hay WW Jr. Hypoglycemia in newborn infants: features associated with adverse outcomes. Biology of the Neonate. 2006;90:74-86.

13. Rozance PJ, Hay, WW Jr. Describing hypoglycemia - definition or operational threshold? Early Hum Dev. 2010; 86(5): 275-280.

14. Rozance PJ. Update on neonatal hypoglycemia. Curr Opin Endocrinol Diabetes Obes. 2014;21(1):45-50.

15. Faustino EV, Hirshberg EL, Bogue CW. Hypoglycemia in critically ill children. J Diabetes Sci Technol. 2012;6(1):48-57.

16. Ishiguro A, Namai Y, Ito YM. Managing "healthy" late preterm infants. Pediatr Int. 2009;51(5):720-725.

17. Sabzehei MK, Basiri B, Bazmamoun H. The Etiology, Clinical Type, and Short Outcome of Seizures in NewbornsHospitalized in Besat Hospital/Hamadan/ Iran. Iran J Child Neurol. 2014;8(2):24-8.

18. Mwaniki M, Mathenge A, Gwer S, Mturi N, Bauni E, Newton CR, et al. Neonatal seizures in a rural Kenyan District Hospital: aetiology, incidence and out come of hospitalization . BMC Medicine. 2010;8(16)

19. Sheth RD, Hobbs GR, Mullett M. Neonatal seizure: Incidence, onset and etiology by gestational age. J Perinatol. 1999;19(1):40-3.

20. Saliba RM, Annegera Jf, Waller DK, Tyson JE. Incidence of Neonatal seizures in harris county. American Journal of epidemiology. 2000;150(7):763-9.

21. Udani V. Long-term prognosis of neonatal seizure - where are we? Indian Pediatr. 2008;45(9):739-41.

22. Tan JH, Poon WB, Lian WB, Ho SK. A Comparison of the Short-term Morbidity and Mortality Between Late Preterm and Term Newborns. Ann Acad Med Singapore. 2014;43(7):346-54.

23. Faiz N, Malik M, Azam M, Afzal U. Etiology and type of neonatal seizures. Ann Pak Inst Med Sci. 2009;5(2):77-86.

24. Digra SK, GuptaA. Prevalence of seizures in hospitalized neonates. JK Science. 2007;9(1):27-9.

25. Tekgul H, Gauvrea K, Soul J, Murphy L, Robertson R, stewart J, et al. The current etiology profile and neurodevelopmental outcome of seizures in term newborn infants. Pediatrics. 2006;117(4):1270-80. 
26. Ross AL, Lombroso CT. Neonatal seizures state. A study of clinical, pathological, and electroencephalographic features in 137 full-term babies with a long-term followup. Pediatrics. 1970;45(3):404-25.

27. Ronen GM, Penney S, Andrew W. The epidemiology of clinical neonatal seizure in new found land, a populationbased study. J Pediatr. 1999;134(1):71-5.

28. Arpino C, Domizio S, Carrieri MP, Brescianini DS, Sabatino MH, Curatolo P. Prenatal and perinatal determinants of neonatal seizures occurring in first week of life. Abs J child Neurol. 2001;16(9):651-6.

29. Nunes ML, Martins MP, BareaBM, Wainberg R C, Costa da Costa J. Neurological outcome of newborns with neonatal seizures. Arq Neuropsiquiatr. 2008;66(2A):168-74.
30. Taksande A, Vilhecar K, Jain M, Lakra M. Clinico- Biochemical Profile of Neonatal Seizures. Indian J Pediatr. 1995;52:424-7.

31. Linder N, Lahat Y, Kogan A, Fridman E, Kouadio F, Melamed N, Yogev Y, Klinger G. Macrosomic newborns of non-diabetic mothers: anthropometric measurements and neonatal complications. Arch Dis Child Fetal Neonatal Ed. 2014;99(5):F353-8.

32. Kanhere S. Recent advances in neonatal seizures. Indian J Pediatr. 2014;81(9):917-25.

33. Adamkin $\mathrm{DH}^{1}$. Neonatal hypoglycemia. Curr Opin Pediatr. 2016;28(2):150-5.

34. Shang $P^{1}{ }^{1}$, Lu GZ, Sun X, Bian ZM, Shang ZY, $\mathrm{Li}$ J. The influence of continuous glucose monitoring of high-risk neonate on guiding perinatal complications and one-year follow-up results. Eur Rev Med Pharmacol Sci. 2016;20(1):125-8.

\title{
Резиме
}

\section{НЕОНАТАЛНА ХИПОГЛИКЕМИЈА: РИЗИК-ФАКТОРИ И ПОСЛЕДИЦИ}

\author{
Орхидеја Стомнароска ${ }^{1 *}$, Елизабета Петковска ${ }^{1}$, Снезана Јанчевска $^{1}$, Драган Даниловски ${ }^{2}$ \\ ${ }^{1}$ Универзитска клиника за гинекологија и акушерство, Медицински факултет Скопје, Македонија \\ ${ }^{2}$ Институт за епидемиологија и статистика, Медицински факултет Скопје, Македонија
}

\section{Апстракт}

Тешката неонатална хипогликемија (НХ) води до невролошки оштетувања, ментална ретардација, нарушувања на личноста, епилепсија, намалување на срцевата функција и мускулна слабост. Нашата цел беше да ја ги анализираме клиничките карактеристики на група новородени со хипогликемија, избрани по случаен избор.

Во ова ретроспективна студија иследивме 84 пациенти (м : ж=35 : 48), кои беа родени во Универзитетската клиника за гинекологија и акушерство и лекувани на Одделот за неонатална интензивна нега. Средната родилна тежина беше 1795,95+/-596,08 грама, средната родилна должина 41,92+/-4,62 цм, средната гестациска возраст $33,05 \pm 3,19$ недели. 32 деца $(38,08 \%)$ имаа многу ниска родилна тежина $(>1500 \mathrm{~g}), 38(4,22 \%)$ беа со многу ниска родилна тежина $(1500-2500 \mathrm{~g})$, родени со соодветна гестациска тежина беа $8(9,52 \%)$, а родени со зголемена телесна тежина немаше.

Траењето на ХГ беше 2,42+/-2,41 часа. 94,4\% од децата беа предвремено родени. Во целост, хипооксично исхемична енцефалопатија имаа 3 деца (3,57\%), инфекции - 22 деца $(26,18 \%)$, респираторен дистрес-синдром - 9 деца (10,62\%), интракранијална хеморагија имаше кај двајца пациенти $(2,38 \%)$. Не беа најдени деца со вродени грешки во метаболизмот. Две деца (2,38\%) завршија летално.

Неонаталната ХГ може да предизвика тежок инвалидитет и е значителен фактор во вкупната неонатална смртност. Студијата покажува дека инфекциите, ниската родилна тежина, малата гестациска возраст се често асоцирани со ХГ. Неонаталната ХГ бара комплексна и тимска соработка и во пренаталниот и во постнаталниот пристап за да се редуцира фреквенцијата и последиците на неонаталната ХГ. Специјална грижа треба да се посвети на намалувањето на бројот и сериозноста на неонаталните инфекции, хипооксично исхемичната енцефалопатија, ниската родилна тежина и малата гестациска возраст. Понатамошни студии со поголеми примероци се потребни за да се разбере целосно феноменот на неонаталната ХГ и за да се преземат мерки за нејзина превенција.

Клучни зборови: неонатална хипогликемија, коморбидности, ниска родилна тежина, морталитет 